\title{
Analyze the Impact of REITs on the Irish Real Estate Market
}

\begin{abstract}
Guolin Wang*
Dundalk Institute of Technology (Dundalk, Co Louth, Ireland)

D00225827@student.dkit.ie

ABSTRACT

In 2008, Ireland's real estate bubble economy burst, which ushered in a real estate market crash and credit crisis in Ireland. The Irish government created the National Assets Administration (NAMA) to purchase bad real estate loans from banks to solve credit problems. In 2013, Ireland introduced the REIT law. The establishment of REIT brought sustainable activities to the real estate market. REIT has attracted many investors and reintroduced working capital to the construction industry. In 2020, COVID-19 began to spread in Ireland. The epidemic greatly limited the development of some real estate and the operation strategy of REIT. This article draws a conclusion through the qualitative analysis of REIT. REIT plays an important role in the recovery of Irish real estate market economy. At the same time, it also has a great impact on Irish real estate market. However, REIT has been established for a long time, so it is impossible to quantify its future performance with existing data.
\end{abstract}

Keywords: REIT, Real Estate market, COVID-19, Ireland.

\section{INTRODUCTION}

The Irish Real Estate Investment Trust was established in 2013. As a connection point between the Irish real estate market and the international financial market, it has successfully attracted many investors with the help of Irish policies and its own advantages. After the collapse of Irish real estate, the government acquired non-performing assets when it established the National Assets Administration (NAMA). These have also become the main factors behind the rapid expansion of REIT in Ireland.

REIT makes Irish real estate more commercial and liquid. And it also has good investment attributes. The arrival of covid-19 also had a great impact on REIT. The higher demand for telework and housing environment has also prompted changes in the real estate market. REIT bears the brunt as a real estate company with many assets. This paper makes a qualitative analysis of REIT. This article will verify the important role of Irish REITs in the real estate market and hope to attract more people's attention to it.

This article mainly analyzes the impact of REIT on the Irish real estate market through the existing reports and secondary data of REIT. The first part of this article introduces basic information about real estate investment trusts. The second part introduces the development background of REIT during 2008-2019. The third part introduces the impact of COVID-19 on real estate.

\section{REAL ESTATE INVESTMENT TRUST}

REIT originated in the United States. As a listed company, the main corporate activity of REITs is the purchase and management of real estate. The real estate investment trust company is the legal owner of real estate. The investment manager is responsible for managing the real estate investment trust portfolio. By attracting investors to invest in local real estate to obtain sufficient capital flow, the shareholders' income has been paid. The REIT has dedicated analysts. They are responsible for customizing an econometric model for real estate, which is about to calculate the digital value of real estate. These data will be opened to investors. This makes real estate investment more intuitive. Investors in REITs gradually changed from speculative investors to long-term investors. These include pension and life insurance funds. For example, TIAA-CREF and Zurich Life Insurance Company [1]. The steady increase in rents brought relatively stable dividends to long-term investors. The period of rapid appreciation of Irish real estate has become history. Most high-quality real estate resources acquired. If REIT is to further expand its income, it must 
speculatively improve the existing real estate. But this will also bring more risks depending on each other.

The Irish Real Estate Trust investment portfolio can diversify the risk of real estate for investors. Investors can also invest in real estate in the form of stocks instead of direct investment. This can help the real estate market to absorb more retail funds. At the same time, REIT is also the main way for private equity investors to exit the Irish real estate market. The volatility level of Irish real estate trusts is lower than that of the stock market. Moreover, the Sharpe ratio of Irish REITs (0.15) is also higher than the Irish stock market $(-0.02)$ [2]. Investors have new choices in their original investment portfolio. REIT provides investors with more diversified income.

\section{DEVELOPMENT OF REIT}

In 2008, the Irish commercial real estate bubble economy burst, and the value of capital and the total rate of return fell off a cliff. This also led to investors withdrawing from the Irish real estate market. The depreciation of speculative real estate has caused many investors to be unable to repay their loans. Following the collapse of Lehman Brothers bank in September 2008, Ireland faced a severe credit crisis. The debt-laden Irish banks are unable to conduct financial activities in the international financial markets. The construction industry has lost its source of funding. The government created the National Assets Administration (NAMA) in 2009 to purchase non-performing real estate loans from banks to eliminate bank credit problems. NAMA pays a market premium of approximately $15 \%$ to increase the value of real estate [1]. The decline in the market value of real estate and NAMA's massive purchase of low-priced assets enabled some investors to see the potential benefits of Irish real estate. In 2011, an organization called the "Irish Real Estate Investment Trust Forum" was established. The Irish government is worried that the real estate market will lose investment value. Under the influence of many factors, Irish government introduced the REIT law in 2013. Investors in the early stage of REITs are mostly opportunistic investors. They make a profit by investing a lot of money in REITs and taking advantage of the rent gap.

\section{IMPACT OF REIT}

REITs used their capital advantage to start large-scale acquisitions of cheap real estate in Ireland. NAMA, which has a large amount of assets, provides a good foundation for the rapid rise of REITs. REITs serve as the connection point between the financial market and the real estate market. REITs provide stability and liquidity for Irish commercial real estate and promote the recovery of the Irish real estate market. Ireland also has many advantages to attract international investors. First, Ireland is a country whose mother tongue is English. This can provide a convenient communication environment for American companies. Second, the corporate tax rate in Ireland is only $12.5 \%$. This very competitive tax rate attracted many multinational companies, such as Facebook, Microsoft, and Google's European headquarters are all set up in Ireland. Thanks to the presence of many companies, there are more job opportunities in Ireland (50,000 new jobs were provided in 2018). Ireland became the fastest growing economy in Europe in 2018. At the same time, Ireland also became the 14th largest economy in Europe and the 23rd largest economy in the world [1]. The rental yield of Irish commercial real estate is higher and stable, and the vacancy rate is also lower. The continuous development of the economy has also become the cornerstone of the good investment prospects of Irish real estate.

However, the large-scale acquisition of Irish real estate by REITs and other real estate buyers has also caused some new problems. First, the active management of assets by REITs and other investors has led to a rapid increase in rents. This will reduce Irish real estate market's competitiveness in the international market. Second, the vacancy rate in Ireland is declining, but the rate of Irish property construction is very low. The shortage of housing, and the large-scale acquisition of land and assets will increase the housing prices in Ireland. This also discourages many home buyers or shoulders higher debts. In the context of the shortage of real estate supply in Ireland, if REIT wants to continue to increase its output value, it must increase the liquidity of real estate to attract more investors. This has also prompted REITs to shift from an acquisition-oriented strategy to a refurbishment and redevelopment strategy. This new strategy enables real estate to meet the requirements of various investors and tenants in real time to promote the sustainable development potential of Irish real estate. At the same time, Irish Real Estate Investment Trust also favors larger spaces to attract corporate tenants. And these buildings have more commercial attributes and no other attributes. These strategies will bring many changes to the urban structure of Ireland.

\section{IMPACT OF COVID-19}

The existence of Covid-19 had a huge impact on the real estate industry. The first wave of Covid-19 blockades and quarantine policies has weakened the operating capacity of European construction companies to 70\%-75\% of normal conditions. And the labor market also begun to lack (Ireland's unemployment rate risen sharply from 5\% at the end of 2019 to $25 \%$ in February 2020) [3]. Retail investors who have lost a stable source of funds will not be able to continue to invest in REIT. Domestic and international transportation has also been hit hard. The transportation of materials will be more expensive. Many factors increased the cost of real estate construction. For industries such as Irish REITs whose main strategy is to 
acquire existing assets, the increase in construction costs will not pose a great financial threat to them.

Demands in this area may change due to COVID-19 but will not decrease as a result. Relatively speaking, the epidemic has a greater impact on commercial real estate. These effects are positive and negative. For example, Ireland's blockade and isolation policies severely hindered the development of tourism. As a result, the hotel industry was more negatively affected [3]. People's daily necessities such as food will not be affected by the epidemic. Therefore, shopping centers centered on the sales of necessities, such as TESCO, LIDL, etc. Therefore, shopping centers centered on the sales of necessities, such as TESCO, LIDL, etc., are still operating well.

Overall, the lasting impact of the epidemic also brought huge uncertainty to the real estate market. This also led to a further increase in the demand for owning high-quality and sustainable real estate .

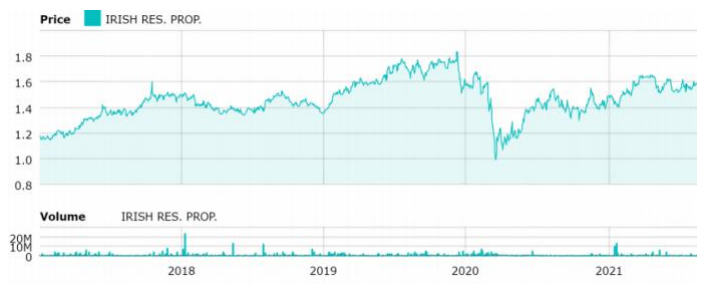

Figure 1. Stock curve of Irish residential properties REIT PLC [4]

Figure 1 shows the stock changes of Irish residential properties REIT PLC from 2014 to 2021. In March 2020, the company's shares fell precipitously. In the following period, the stock began to rise. The major blockade at the beginning of the epidemic caused panic among the people. Most people chose to stay at home and waited for the epidemic to dissipate. Therefore, during this period, the shares of Irish Residential Properties REIT PLC plummeted. However, with the gradual effect of the lockdown policy and the government's subsidy for unemployment due to the epidemic, the people adapted to the existence of COVID-19 and the economy begun to recover. Even in the second and third outbreaks of the Irish epidemic, the shares of Irish Residential Properties REIT PLC remained relatively stable, but they did not return to their pre-epidemic levels. This also means that during the COVID-19 period, the real estate market received a certain negative impact, but the overall situation is relatively safe.

\subsection{Rent price}

Irish rents have been rising rapidly from 2010 . Moreover, REITs usually target real estate that is underleased or about to expire. This means that in the next cycle, rents will have a significant increase. On the other hand, the shortage of real estate in Ireland will further increase rents. But COVID-19 curbed the upward trend of rents. According to the Residential Tenancy Board (RTB), Dublin's rents increased by $2.7 \%$ in 2020 . This figure is significantly lower than the $6.7 \%$ increase in 2019 [5]. The Irish Residential Real Estate REIT PLC pointed out at the annual general meeting of shareholders, At the end of December 2020, their company's real estate occupancy rate was as high as $98.4 \%$. From April 1, 2020, the company has also suspended rent increases for renewals [6].

\subsection{Real estate development direction}

COVI-19 will also trigger major changes in real estate. Before the epidemic, the company continued to reduce its employees' personal office space to reduce fixed costs. However, after the epidemic, remote work such as home office and online meetings emerged. After quarantining and restricting access, many people will maintain their current remote working mode. This will reduce corporate demand for real estate. REIT may face the problem of rising real estate vacancy rate in the future. According to a British study [3], the long-term isolation policy caused great changes in people's demand for residential housing. The requirements for house comfort, such as sound insulation, heat insulation, air quality and daylighting, have attracted more and more attention. This upgrade and improvement of existing houses may become the focus of REIT's next work. With the continued spread of COVID19 , healthy buildings in the real estate industry received attention from many industries.

\section{CONCLUSION}

This article analyzes the important role of the Irish Real Estate Investment Trust in the collapse of the real estate bubble in 2008 and the impact of COVID-19 on the Irish real estate market. According to the actual situation, REIT successfully reconnected the international financial market and the Irish real estate market. During this period, REIT developed rapidly. Investors are also increasingly favoring the Irish real estate market. However, Ireland's real estate construction rate lags far behind growing demand. Rents and house prices started to rise again rapidly. This makes Ireland may face another boom-bust cycle. For now, the Irish Real Estate Investment Trust Company has a huge real estate resource. This may lead to an oligopoly in the Irish market.

In terms of investment, Irish REITs already brought substantial returns to investors. But with the real estate's rate of return is also declining. The subsequent COVID19 brought many negative effects on the real estate industry. People also began to have new demands for residential and commercial real estate. REIT will also change its investment strategy in response to this change. Overall, COVID-19 only temporarily curbed the rapid development of Irish real estate. House prices and rents 
in Ireland will continue to rise after the epidemic. But the rise of remote work will have a big impact on the commercial real estate market. Ireland's urban structure will also usher in new changes. However, the establishment of Irish real estate investment trusts is still relatively short. The research still need more data and samples to further analyze REIT.

\section{REFERENCES}

[1] Waldron R. Capitalizing on the State: The political economy of Real Estate Investment Trusts and the 'Resolution' of the crisis. Geoforum. 2018;90:206218. doi:10.1016/j.geoforum.2018.02.014

[2] Marzuki MJ, Newell G, McGreal S. The development and initial performance analysis of REITs in Ireland. Journal of Property Investment \& Finance. 2019;38(1):56-70. doi:10.1108/JPIF-082019-0114

[3] Kaklauskas A, Zavadskas EK, Lepkova N, Raslanas S, Dauksys K, Vetloviene I, Ubarte I. Sustainable Construction Investment, Real Estate Development, and COVID-19: A Review of Literature in the Field. Sustainability.

2021;13(13):7420. doi:10.3390/su13137420

[4]IRISH RESIDENTIAL PROPERTIE SREITPLC $€ 1.54$.[accessed2021Aug29].https://live.euronext.c om/en/product/equities/IE00BJ34P519-XMSM

[5] Burke-Kennedy E. Rental costs rise by $2.7 \%$ in 2020 as Dublin rents average $€ 1,745$. The Irish Times. [accessed2021 Aug16].https://www.irishtimes.com/ business/economy/rental-costs-rise-by-2-7-in2020-as-dublin-rents-average-1-745-1.4518743

[6] Irish Residential Properties REIT PLC Annual Shareholders Meeting - Final. Fair Disclosure Wire (Quarterly Earnings Reports). [accessed 2021 Aug 15]. https://search.ebscohost.com/login.aspx?direct=tru e\&AuthType $=$ sso,cpid\&custid $=$ ns000798 \&db=bwh $\& \mathrm{AN}=32 \mathrm{U} 0347241975 \mathrm{FDW} \&$ site $=$ eds-live 